\title{
The mediating role of security and privacy on the relationship between customer interface features and e-word of mouth marketing
}

\author{
Müşteri ara yüz özellikleri ile e-ağızdan ağıza pazarlama arasındaki \\ ilişkide güvenlik ve gizliliğin aracılık rolü
}

${ }^{1}$ Assist. Prof., Trakya University, Edirne, Turkey, pinaryuruk@trakya.edu.tr

ORCID: 0000-0002-7460-6465

Submitted: 9/07/2021

Revised: $12 / 08 / 2021$

Accepted: 16/08/2021

Online Published: 25/08/2021

Citation: Yürük-Kayapınar, P., The mediating role of security and privacy on the relationship between customer interface features and e-word of mouth marketing, tujom (2021) 6 (2):125-142, doi: https://doi.org/10.30685/tujom.v6i2.118
Pınar Yürük-Kayapınar ${ }^{1}$

\begin{abstract}
Recent developments in technology have led to an increase in Internet usage by consumers and businesses. This study examines the relationships between customer interface features, security and privacy, electronic word of mouth marketing and online purchasing intentions. In order to examine these relationships, a total of 438 consumers were reached from Edirne, Tekirdağ and Kirklareli provinces by using the convenience sampling method. According to the research aim, consumers who made purchases via e-commerce sites were selected, and data were collected by interviewing these people face to face. In order to analyze the collected data, first explanatory and confirmatory factor analyzes were applied and then the hypotheses were tested with the structural equation model. According to the results, customization and character directly affect security and privacy, whereas interaction, character, and customization directly affect electronic word of mouth marketing. Thus, security and privacy have a significant direct effect on the electronic mouth of mouth marketing, while customization has a significant direct effect on online purchasing intention. In addition, customization and character significantly affect electronic word of mouth marketing through the mediating role of security and privacy.
\end{abstract}

Keywords: Customer Interface Features, Security and Privacy, Electronic Word of Mouth Marketing

Jel Codes: M30, M31, M39

Öz

Teknolojideki son gelişmeler, tüketiciler ve işletmeler tarafından internet kullanımının artmasına neden olmuştur. Bu çalışma, müşteri arayüzü özellikleri, güvenlik ve gizlilik, elektronik ağızdan ağıza pazarlama ve çevrimiçi satın alma niyetleri arasındaki ilişkileri incelemektedir. Bu ilişkileri incelemek için, Edirne, Tekirdağ ve Kırklareli illerinden, kolayda örneklem yöntemi kullanılarak toplam 438 tüketiciye ulaşılmıştır. Araştırmanın amacına göre, e-ticaret siteleri üzerinden alışveriş yapan tüketiciler seçilmiş ve bu kişilerle yüz yüze görüşülerek veriler toplanmıştır. Toplanan verileri analiz etmek için, öncelikle açıklayıcı ve doğrulayıcı faktör analizleri uygulanmış ve daha sonrasında hipotezler yapısal eşitlik modeli ile test edilmiştir. Elde edilen sonuçlara göre, kişiselleştirme ve karakterin güvenlik ve gizlilik üzerinde; etkileşim, karakter ve kişiselleştirme ve güvenlik ve gizliliğin elektronik ağızdan ağıza pazarlama üzerinde; kişiselleştirmenin de çevrimiçi satın alma niyeti üzerinde anlamlı doğrudan bir etkisi görülmektedir. Ayrıca, kişileştirme ve karakter, güvenlik ve gizliliğin aracılık rolü sayesinde elektronik ağızdan ağıza pazarlama üzerinde anlamlı dolaylı bir etkiye sahiptir.

Anahtar Kelimeler: Müşteri Arayüz Özellikleri, Güvenlik ve Gizlilik, Elektronik Ağızdan Ağıza Pazarlama

IEL Kodlari: M30, M31, M39 


\section{Introduction}

The growing number of Internet users and electronic commerce (e-commerce) potential inviting individuals to make online purchases have brought a new dimension to a business-consumer relationship (McCole, Ramsey \& Williams, 2010). The frequent use of the Internet increases the number of online transactions and the likelihood of becoming an e-consumer who prefer buying products and services from e-commerce sites. Online Purchasing involves the stages of decision-making by consumers. In addition, the Internet is an important medium to do some research before purchase and share positive/negative experiences after purchase. Therefore, it incorporates many functions, unlike the traditional purchasing process.

Shopping from an e-commerce site and feeling satisfied with the shopping experience is directly related to the customer interface features of the e-commerce site, which have the potential to influence consumers' behaviour on the Internet. If the consumer is satisfied with the interface features of an ecommerce site, which constitutes an element of trust, he or she will be comfortable with the purchase. Otherwise, the consumer will leave the e-commerce site immediately, and it will probably take time for the e-commerce site to regain that consumer's trust. Consumers' trust is often shaped based on the trust and privacy policy provided by the site, which makes it one of the essential factors in e-commerce (Gefen, 2000; Corbitt, Thanasankit \& Yi, 2003). After the trust in the e-commerce site is established, security and privacy bring customer satisfaction. Because in an electronic environment, security and privacy are among the most critical factors for customer satisfaction (Girsang, Herdayani \& Ganesan, 2020; Siahaya, Amelia, \& Suryaputra, 2021).

There are many studies on online purchasing where customer interface is taken as a variable (Constantinides, 2004; Schlosser, White \& Lloyd, 2006; Sam, Fazli \& Tahir, 2009). However, no study was found in which the variables of customer interface, security and privacy, electronic word of mouth marketing and online purchasing intention were used. Therefore, the main aim of the present study is to examine the relationships between these variables. As a result, the research model developed using these variables differs from previous studies. In line with the main aim of the study, we aim to examine (1) the direct effects of customer interface variables (contact interactivity, customization, convenience, character) on security and privacy, electronic word of mouth marketing, and online purchasing intention; (2) the direct effect of security and privacy on electronic word of mouth marketing; (3) the direct effect of electronic word-of-mouth marketing on online purchasing intention; and (4) the indirect effect of customer interface features on electronic word of mouth marketing through the mediating role of security and privacy.

\section{Literature review}

\section{Customer interface features}

E-commerce includes all transactions related to product or service purchases performed over the Internet using computer technologies. Customers who intend to view or purchase a product or service have to interact with an interface. Therefore, each factor that will affect customer behaviours in this interface should be identified and defined very well. The quality of the customer interface is associated with many factors, and it requires a multifaceted perspective.

The customer interface establishes a framework with a specific role, enabling communication between retailers and customers and giving value to them (Lee \& Benbasat, 2004). The design of this framework is critical as it has the potential to turn visitors into customers. Therefore, website designers should carefully select the content and design of the website in order to influence the purchasing desires and attitudes of consumers and customers (McDowell, Wilson \& Kile, 2016) and ensure quality (Vila, González, Vila \& Brea, 2021). The quality of a website is measured by the extent to which it meets customer needs and desires and reflect excellence (Aladwani \& Palvia, 2002). In order to achieve this, 3D product presentations, visual design, colours, fonts, shapes must be in order (Zhang, Fiore, Zhang $\&$ Liu, 2021). Thus, the quality of the website will increase, and interactive communication will be provided more efficiently. The fact that a website is interactive plays a vital role in improving consumer perceptions and attitudes (Islam, Jebarajakirthy \& Shanker, 2021).

There is an extensive body of literature on customer interface, e-commerce and website quality. Different studies have employed different factors. There are no clear guidelines on the website's design 
or how to improve the service quality (Forgas-Coll, Palau-Saumell, Sanchez-Garcia \& Fandos-Roig, 2013). Different factors have been considered in different studies on how an interface should be. Lee \& Benbasat (2004) examined context, content, community, customization, communication, connection and commerce, and expressed them as 7Cs. Ho \& Lee (2007) state that information quality, security, functionality, customer relations and sensitivity are the five factors that affect website quality. Similarly, Srinivasan, Anderson \& Ponnavolu (2002) identify eight factors affecting website quality: customization, contact interactivity, cultivation, care, community, choice, convenience, and character as 8Cs. In contrast, Chang \& Chen (2008a) uses a framework including four factors drawing from Srinivasan et al. (2002): customization, contact interactivity, convenience, and character. Bridges \& Florsheim (2008) uses skill, control, interactivity and importance. The current study follows the steps by Chang \& Chen (2008a) and Srinivasan et al. (2002)

Customization is defined as the ability of an e-retailer to adapt products, services and transactions to individual customers (Srinivasan et al., 2002), and it expresses the ability of a website to change itself for each user (Lee \& Benbasat, 2004). From a customer perspective, customization is a crucial element that enables an e-retailer to focus on the products or services a customer wants to buy (Chang \& Chen, 2008a). Contact Interactivity refers to the dynamic nature of participation between an e-retailer and a customer via the website (Srinivasan et al., 2002) and two-way communication. Convenience is the ability to browse a website comfortably and use it efficiently (Chang \& Chen, 2008a). In a study conducted by Schaffer (2000), 30\% of the customers who visited a website and left without buying any products were surveyed for their reasons for not buying. The results showed that the reason for not purchasing anything was that the website design was perceived as challenging to use. Therefore, the user-friendly and convenient design of an e-commerce site seems to be of utmost importance for consumers. Character is another factor suggested by Wang \& Emurian (2005). It is defined as the design features that provide the first impression to the customers belonging to an e-retailer website and is expressed as a general image and personality projected to the customers considering the features of the website such as text, style, logo, slogan and theme (Srinivasan et al., 2002). The positive of all these features means that the quality of the website. Consumers who form positive perceptions after visiting and experiencing a website are more likely to develop perceived quality.

\section{Security and privacy}

According to McCole et al. (2010) and Ardiansah, Chariri, Rahardija \& Udin (2020), security and privacy are two of the essential variables in online purchases. Security and privacy are closely related to consumers' access to an e-commerce site and their browsing and purchasing behaviours. An individual who does not feel safe and feels that the personal information given to the e-commerce site is not protected will tend to leave that e-commerce site. Security and privacy include the security of credit card payments and the privacy of shared information (Kim, Jin \& Swinney, 2009) and refers to the security and privacy of personal and financial information (Yoo \& Donthu, 2001). The privacy of consumer information collected for commercial purposes is seen as a legal and ethical right. However, it is not enough to store consumer information safely, and it must be protected in such a way that no one else can access it (Miyazaki \& Fernandez, 2001). Early research on e-commerce suggests that any risk to the security and privacy of consumers' personal information prevents consumers from adopting the Internet as a means of purchasing goods and services (Hui, Teo \& Lee, 2007). According to Szymanski \& Hise (2000), 75\% of Internet users emphasize that credit card security is important when deciding whether to shop from an e-commerce site. In addition, Kim \& Kim (2004) state that the availability of security and privacy and secure digital systems increases the number of consumers visiting and purchasing e-commerce sites. Wolfinbarger \& Gilly (2003) studied the relationship between a website and security and privacy, emphasize that website design, fulfilment, and customer service are superior to privacy and security for most consumers. Kim et al. (2009) posit that when consumers believe that a website is sensitive to security and privacy issues, they tend to trust that website and do the shopping more comfortably.

Similarly, Miyazaki \& Fernandez (2001) suggest that security and privacy are of utmost importance to many Internet users. Ackerman, Cranor \& Reagle (1999) and Anton, Earp \& Reese (2002) claim that the privacy feature of a website is the most necessary, whereas $\mathrm{Li}$ (2014) adds that it is the most important factor shaping the behaviour of consumers on the Internet and many studies reveal that privacy is the most crucial determinant of a web site's features. Belanger, Hiller \& Smith (2002) have studied the 
relationship between the features of a website and security and privacy and suggest that security is the essential factor for the consumer. Therefore, the following hypotheses are tested:

H1: Customer interface features have a significant direct effect on security and privacy.

H1a: Contact interactivity has a significant direct effect on security and privacy.

H1b: Customization has a significant direct effect on security and privacy.

H1c: Convenience has a significant direct effect on security and privacy.

H1d: Character has a significant direct effect on security and privacy.

\section{Electronic word of mouth marketing (eWOMM)}

Unlike traditional consumers, online consumers are communicating with many more consumers. This situation has caused the concept of WOMM to change. Thanks to this digital environment, they have reached a broader audience in businesses and started to examine consumers' experiences in this digital environment (Yuruk-Kayapinar, 2020). These digital environments and technologies have made WOMM even more critical, especially regarding purchasing impact (Rosario, Valck \& Sotgiu, 2020). In this digital scenario, eWOMM is defined as online reviews, recommendations, and online reviews (Serra-Cantallops, Cardona \& Salvi, 2020). Brown, Broderick \& Lee (2007) maintains that platforms that include consumers' comments who share their experiences are considered the essential source of information. In an online shopping environment, online purchasing experiences may reduce uncertainties, which leads to an increase in consumers' purchasing intentions. Users who buy products over the Internet, i.e., online shoppers, are more willing to shop online than other consumers (Thamizhvanan \& Xavier, 2013). Lopez \& Sicilia (2014) and Yoo, Sanders \& Moon (2013) state that there is a direct relationship between eWOMM and the experiences of consumers on the Internet, whereas Ha \& Im (2012) have identified an indirect relationship between eWOMM and website design quality. Tran, Strutton \& Taylor (2012) indicate that the more consumers trust a website, the more they share their feelings with others. Chung \& Shin (2010) posit that consumers' trust in the Internet positively and directly affect eWOMM. Therefore, the following hypotheses are tested:

$\mathrm{H} 2$ : Customer interface features have a significant direct effect on eWOMM.

H2a: Contact interactivity has a significant direct effect on eWOMM.

$\mathrm{H} 2 \mathrm{~b}$ : Customization has a significant direct effect on eWOMM.

H2c: Convenience has a significant direct effect on eWOMM.

H2d: Character has a significant direct effect on eWOMM.

H3: Security and privacy have a significant direct effect on eWOMM.

\section{Online purchasing intention}

The purchasing intention is the decision-making process where consumers buy a particular brand (Mirabi, Akbariyeh \& Tahmasebifard, 2015). However, it has turned into an online process with the spread of the Internet and globalization, and now most consumers can access any product from anywhere.

Online purchasing is expressed as electronic commerce, where consumers spend their money buying goods or services from an online store (Kazmi, Hai \& Abid, 2016). It is often considered riskier than offline purchases (Thamizhvanan \& Xavier, 2013). A customer's online purchasing experience involves information search, product evaluation, decision-making, processing, delivery, returns and customer service (Wolfinbarger \& Gilly, 2003). Schlosser et al. (2006) suggest a link between the design and features and the online purchasing intention, while Constantinides (2004) asserts an association between consumers' website experiences and their online purchasing intentions. Sam et al. (2009) conclude that there is a direct relationship between the quality features and consumers' online purchases. Bickart and Schindler (2001), Chevalier \& Mayzlin (2006), See-To \& Ho (2014), Erkan \& Evans (2016), MartinezNavarro \& Bigne (2017) and Ngarmwongnoi, Oliveira, AbedRabbo \& Mousavi (2020) point out that electronic word-of-mouth marketing is an essential factor that affects consumers' purchasing intentions. Therefore, the following hypotheses are tested: 
H4: Customer interface features have a significant direct effect on online purchasing intentions.

H4a: Contact interactivity has a significant direct effect on online purchasing intentions.

H4b: Customization has a significant direct effect on online purchasing intentions.

H4c: Character has a significant direct effect on online purchasing intentions.

$\mathrm{H} 4 \mathrm{~d}$ : Convenience has a significant direct effect on online purchasing intentions.

H5: eWOMM has a significant direct effect on online purchasing intentions.

There is an extensive body of literature on website quality and online purchasing behaviour. For instance, Lee \& Benbasat (2004) explain how the customer interface design for mobile commerce should be while Kim et al. (2008) elaborates on the relationship between trust and website quality and online purchasing behaviour. Forgas-Coll et al. (2013) focus on the relationship between website quality, loyalty, trust variables and demographic factors, gender and education factors. Slyke (2002) explores the relationship between credit cards, computer experience and online purchasing. Similarly, Sin \& Tse (2002) and Cengiz \& Sekerkaya (2010) discuss the relationship between demographic variables and online purchasing. Heijden, Verhagen \& Creemers (2003) have investigated the factors affecting consumers' online purchases from an e-commerce site. Verhagen \& Dolen (2009) have examined online store perceptions on online purchasing, and Lim, Osman, Salahuddin, Romle \& Abdullah (2016) have found an association between online shopping behaviour and purchase intention. When the literature is examined, it is seen that there are studies that test the relationships between customer interface features, security and privacy and eWOMM separately. McCole et al. (2010) and Ardiansah et al. (2020) mention that security and privacy are essential moderator variables. However, no study has been found in which these three variables are considered together, especially the mediating role of security and privacy. Therefore, the following hypotheses are tested in this study, unlike the others:

H6: Customer interface features significantly affect electronic word of mouth marketing through security and privacy.

H6a: Contact interactivity has a significant indirect effect on electronic word of mouth marketing through security and privacy.

H6b: Customization has a significant indirect effect on electronic word of mouth marketing through security and privacy.

H6c: Convenience has a significant indirect effect on electronic word of mouth marketing through security and privacy.

H6d: Character has a significant indirect effect on electronic word of mouth marketing through security and privacy.

\section{Methodology}

\section{Research model}

The main aim of the present study is to examine the relationship between customer interface features (customization, contact interactivity, convenience and character) that help make an e-commerce business successful and the security and privacy, electronic word of mouth marketing, and online purchasing intention. By the aim of the study, the direct relationships between the following pairs of variables are investigated: (1) customer interface features and security and privacy; (2) customer interface features and electronic word of mouth marketing; (3) security and privacy and electronic word of mouth marketing; (4) customer interface features and online purchase intention; (5) electronic word of mouth marketing and online purchasing intention; and finally, the mediating role of security and privacy, i.e. indirect relationship in the effect of customer interface features on electronic word of mouth marketing is investigated. These relationships are tested separately, as shown in Model 1 and Model 2. The mediation effect revealed a third variable that interferes with the relationship between two related structures or variables. In other words, the third variable strengthens, reduces or eliminates the relationship between two variables that affect each other (Kayapınar, 2018). In order to build the structure as a whole, direct effects should be tested first, and then the changes in the model should be reviewed with the inclusion of mediation effects (Hayes, 2013). Model 1 shows only direct effects, 
whereas Model 2 values the direct and indirect (mediation) effects resulting from the inclusion of security and privacy as a mediator. Therefore, Model 1 is created to support Model 2, which is the primary model of the current study. In Model 1, H1, H2 and H4, hypotheses are tested, and in Model 2, $\mathrm{H} 1, \mathrm{H} 2, \mathrm{H} 3, \mathrm{H} 4, \mathrm{H} 5$, and H6, hypotheses are tested. The research model in Figure 1 is formed based on the research objectives and the related literature review of the research.

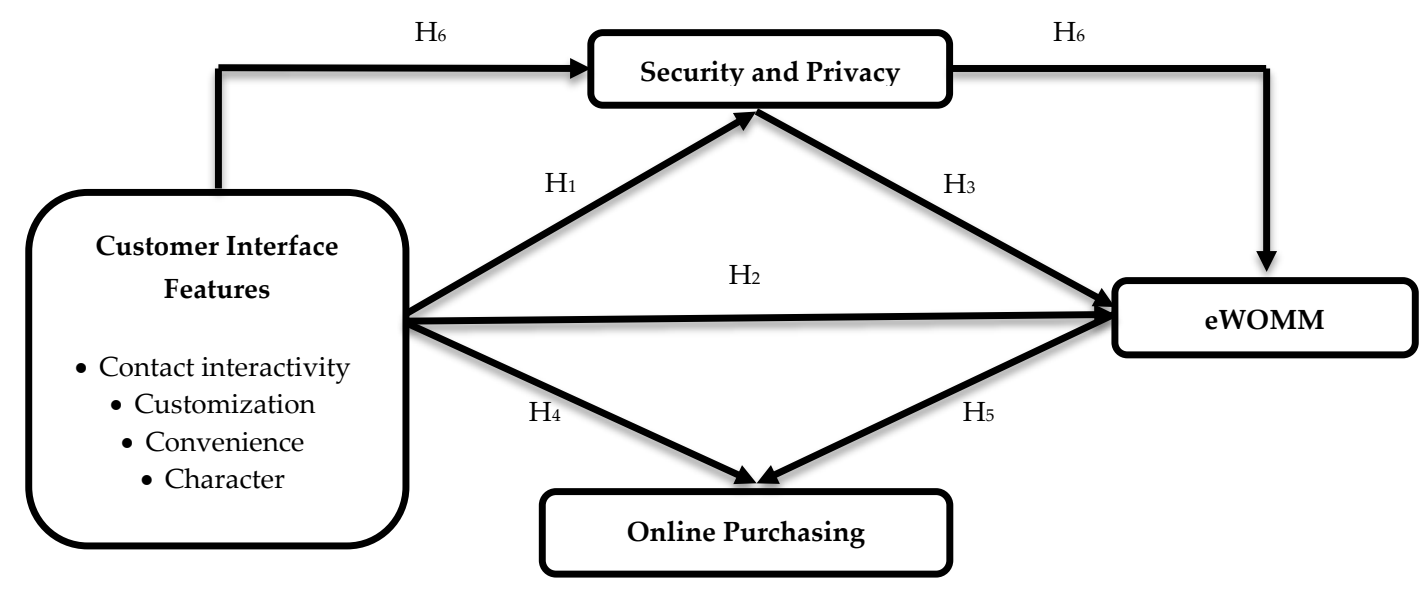

Figure 1. Research Model

\section{Data collection method and tools}

The variables are derived from the research whose validity and reliability have been tested to measure customer interface features (Srinivasan et al., 2002), security and privacy (Wolfinbarger \& Gilly, 2003), electronic word of mouth marketing (Jalilvand \& Samiei, 2012), and online purchasing intention (Chang \& Chen, 2008b). There are 20 items for customer interface features (customization-5 items, contact interactivity-5 items, convenience- 5 items and character-5 items), 11 items for security and privacy, six items for eWOMM and three items for online purchasing intentions. All the items are rated on a 5-point scale $(1=$ Strongly Disagree, 5 = Strongly Agree). The original items are in English. So, they are translated into Turkish.

Data were collected in Edirne, Tekirdag and Kirklareli provinces in Turkey using the convenience sampling method; consumers who made purchases via e-commerce sites were selected as the target of the research, and these individuals were interviewed face-to-face to collect the data. These three provinces were included in the study to reach consumers more quickly due to the size of the population and time and cost constraints. Ethics committee approval was obtained from Trakya University Social and Human Sciences Research Ethics Committee with the decision numbered 02/44 on 24.02.2021 for the questionnaire used to collect research data.

Twelve questionnaires with missing data were excluded from the study, and a total of 438 questionnaires were included in the data analysis. There are many suggestions in the literature regarding determining the sample size to be used in the research. For example, it is a generally accepted selection method that the sample chosen to represent a universe is between 5 and 10 times the number of expressions in the scale (Hair, Black \& Babin, 2010; Kline, 2011). In addition, according to another suggestion, a sample of 100-400 is considered sufficient for Structural Equation Modeling (Hair et al., 2010). As a result, the sample of the research represents the universe.

\section{Data analysis and findings}

The frequency distributions of some socio-demographic characteristics of 438 participants are as follows: $53.9 \%$ of the participants are women, 51.1\% are married, $46.1 \%$ have an associate's degree, $69.9 \%$ are between $28-36$ years of age, $57.5 \%$ have a personal income ranging between $3201-4700$ Turkish Liras, 42.2\% have a household income ranging between 3001 - 5000 Turkish Liras and 52.1\% make purchases on the Internet at least once a month. 
Table 1: The Results of EFA

\begin{tabular}{|c|c|c|c|c|}
\hline Scales & $\begin{array}{c}\text { Factor } \\
\text { Loadings }\end{array}$ & $\begin{array}{l}\text { Variance } \\
\text { Explained } \\
(\%)\end{array}$ & $\begin{array}{l}\text { Eigen- } \\
\text { Values }\end{array}$ & $\begin{array}{l}\text { Cronbach } \\
\text { Alfa } \\
(\alpha)\end{array}$ \\
\hline $\begin{array}{l}\text { Customer Interface Features (CIF) }{ }^{a, b, c} \\
\text { KMO: 0.809; } \\
\text { Bartlett's test; }\left(\chi^{2=3791.809 ;} \mathrm{df}=153 ; \mathrm{p}=0.000\right)\end{array}$ & & 66.295 & & 0.803 \\
\hline Character (Cha) & & 19.323 & 3.478 & 0.889 \\
\hline This website design is attractive to me. & 0.875 & & & \\
\hline For me, shopping at this website is fun. & 0.869 & & & \\
\hline This website does not feel inviting to me. & 0.835 & & & \\
\hline I feel comfortable shopping at this website & 0.768 & & & \\
\hline This website does not look appealing to me. & 0.763 & & & \\
\hline Convenience (Con) & & 17.400 & 3.132 & 0.842 \\
\hline $\begin{array}{l}\text { Navigation through this website is not very intuitive. } \\
\text { A first-time buver can purchase from this website without much help. } \\
\text { It takes a long time to shop at this website. }\end{array}$ & $\begin{array}{l}0.823 \\
0.783 \\
0.772\end{array}$ & & & \\
\hline This website is a user-friendly site. & 0.757 & & & \\
\hline This website is very convenient to use. & 0.714 & & & \\
\hline Customization (Cust) & & 15.802 & 2.844 & 0.855 \\
\hline $\begin{array}{l}\text { This website makes me feel that I am a unique customer. } \\
\text { The advertisements and promotions that this website sends to me are tailored to } \\
\text { my situation. }\end{array}$ & $\begin{array}{l}0.880 \\
0.861\end{array}$ & & & \\
\hline This website enables me to order products that are tailor-made for me. & 0.843 & & & \\
\hline I believe that this website is customized to my needs. & 0.742 & & & \\
\hline Contact interactivity (Int) & & 13.769 & 2.478 & 0.792 \\
\hline $\begin{array}{l}\text { This website does not have a tool that makes product comparisons easy. } \\
\text { This website enables me to view the merchandise from different angles. }\end{array}$ & $\begin{array}{l}0.828 \\
0.783\end{array}$ & & & \\
\hline I feel that this is a very engaging website. & 0.766 & & & \\
\hline This website has a search tool that enables me to locate products. & 0.731 & & & \\
\hline $\begin{array}{c}\text { Security-Privacy }(\mathrm{SP})^{\mathrm{a}, \mathrm{b}} \\
\text { KMO: } 0.898 ; \\
\text { Bartlett's test; }(\chi 2=3911.844 ; \mathrm{df}=28 ; \mathrm{p}=0.000)\end{array}$ & & 75.504 & 6.040 & 0.953 \\
\hline $\begin{array}{l}\text { I feel I can trust this website. } \\
\text { I feel like my privacy is protected at this site }\end{array}$ & $\begin{array}{l}0.953 \\
0.929\end{array}$ & & & \\
\hline I feel safe in my transactions with this website & 0.888 & & & \\
\hline The website gives confidence to customers. & 0.882 & & & \\
\hline I feel secure giving out credit card information at this site. & 0.859 & & & \\
\hline $\begin{array}{l}\text { I trust that this site will not give my information to other sites without my } \\
\text { permission. }\end{array}$ & 0.828 & & & \\
\hline The company is well-established. & 0.826 & & & \\
\hline The company behind the site is reputable & 0.772 & & & \\
\hline $\begin{array}{l}\text { Electronic Word of Mouth Marketing (eWOMM) })^{\mathrm{a}, \mathrm{b}} \\
\text { KMO: } 0.842 ; \\
\text { Bartlett's test; }(\chi 2=1805.902 ; \mathrm{df}=10 ; \mathrm{p}=0.000)\end{array}$ & & 74.926 & 3.746 & 0.915 \\
\hline $\begin{array}{l}\text { I often consult other consumers' online product reviews to help choose the right } \\
\text { product/ brand. }\end{array}$ & 0.937 & & & \\
\hline $\begin{array}{l}\text { To make sure I buy the right product/ brand, I often read other consumers' online } \\
\text { product reviews. } \\
\text { I frequently gather information from online consumers' product reviews before I } \\
\text { buy a particular product/brand. }\end{array}$ & $\begin{array}{l}0.896 \\
0.881\end{array}$ & & & \\
\hline $\begin{array}{l}\text { I often read other consumers' online product reviews to know what } \\
\text { products/brands make good impressions on others. }\end{array}$ & 0.848 & & & \\
\hline $\begin{array}{l}\text { When I buy a product/brand, consumers' online product reviews make me } \\
\text { confident in purchasing the product/brand. }\end{array}$ & 0.755 & & & \\
\hline $\begin{array}{c}\text { Online Purchasing Intention (OPI) }{ }^{\mathrm{a}, \mathrm{b}} \\
\text { KMO: 0.702; } \\
\text { Bartlett's test; }(\chi 2=710.564 ; \mathrm{df}=3 ; \mathrm{p}=0.000)\end{array}$ & & 79.670 & 2.390 & 0.872 \\
\hline I expect to purchase through $X^{\prime}$ s website in the future. & 0.929 & & & \\
\hline I intend to use $X^{\prime}$ 's website to conduct product purchases. & 0.898 & & & \\
\hline I will likely transact with X's website shortly. & 0.849 & & & \\
\hline
\end{tabular}


Note: aExtraction Method: Principal Component (PC)

bRotation Method: Varimax with Kaiser Normalization

cRotation converged in 5 iterations

Explanatory and confirmatory factor analyses and then the structural equation model is employed to test the hypotheses. Factor analysis is used to explore the relationship between multiple variables (Gegez, 2010), and it describes the structure of the relationship between the variables (Hair, Black, Babin \& Anderson, 2009). Although the scales used in the current study are derived from previous research and proved accurate and reliable, exploratory factor analysis (EFA) is done to test their applicability in the Turkish context. Data is prepared for structural equation modelling (SEM), and the model is evaluated (Kline, 2011; Tabachnick \& Fidell, 2013). KMO and Bartlett Tests are used to determine whether factor analysis is needed (Kaiser \& Rice, 1974). KMO and Bartlett's test values, loadings, \% of the variance, eigenvalues and reliability values (Cronbach $\alpha$ ) of the scales are presented in Table 1.

The KMO and Bartlett's test results show that the data is suitable for factor analysis (Kaiser \& Rice, 1974). For customer interface, the factor loadings of character, convenience, customization and contact interactivity ranged between 0.875 and $0.763,0.823$ and $0.714 ; 0.880$ and $0.742 ; 0.828$ and 0.731 , respectively. For security and privacy, eWOMM and online purchasing intention, they ranged between 0.953 and $0.772 ; 0.937$ and $0.755 ; 0.929$ and 0.849 , respectively. Character, convenience, customization, and contact interactivity explain $19.323 \%, 17.400 \%, 15.802 \%$, and $13.769 \%$ of the total variance. These four factors that constitute the customer interface scale explain $66.295 \%$ of the total variance, which is sufficient. According to Alpar (2013), Byrne (2010), Kline (2011), Tabachnick \& Fidell (2013), the total variance explained should be $60 \%$ or more. As shown in Table 1 , security and privacy, eWOMM, and online purchasing intention explained $75.504 \%, 74.926 \%$ and $79.670 \%$ of the total variance, respectively. In addition, the eigenvalues of these factors meet the rule of being greater than 1 (Fabrigar, Maccallum, Wegener \& Strahan, 1999). Cronbach's Alpha $(\alpha)$ values are higher than 0.70 for all factors, indicating high reliability. $\alpha$ values should be between 0 and 1 . Especially $\alpha$ values above 0.70 are highly reliable (Cronbach, 1951; Perreault \& Leigh, 1989). Confirmatory Factor Analysis (CFA) is used to verify the factors structures revealed by Exploratory Factor Analysis (EFA) and ensure reliability and validity.

Table 2: Goodness of fit indices in CFA

\begin{tabular}{|c|c|c|c|c|c|c|c|c|c|c|c|}
\hline Factors & $x^{2}$ & sd & $\chi^{2 / s d}$ & RMSEA & GFI & AGFI & RMR & SRMR & CFI & NFI & $\begin{array}{c}\text { TLI } \\
\text { (NNFI) }\end{array}$ \\
\hline CIF & 303.624 & 128 & 2.372 & 0.056 & 0.929 & 0.906 & 0.066 & 0.046 & 0.953 & 0.921 & 0.943 \\
\hline SP & 27.369 & 9 & 3.042 & 0.068 & 0.985 & 0.941 & 0.011 & 0.017 & 0.995 & 0.993 & 0.985 \\
\hline OPIa & - & - & - & 0.328 & 1.000 & - & 0.000 & 0.000 & 1.000 & 1.000 & - \\
\hline eWOM & 1.195 & 1 & 1.195 & 0.021 & 0.999 & 0.984 & 0.006 & 0.004 & 1.000 & 0.999 & 0.999 \\
\hline
\end{tabular}

The model for the goodness of fit indices in Table 2 shows that the values are sufficient for the application of SEM, that they explain the relevant factors and items, and that the scales used generally show acceptable and good fit (Hooper, Coughlan \& Mullen, 2008; Hu \& Bentler, 1999; Kline, 2005; Schermelleh-Engel, Moosbrugger \& Müller, 2003). CFA for the OPI scale shows that the scale's degree of freedom (df) was zero and a saturated model. The saturated model always ensures a perfect fit to the data so that the expected frequencies are precisely equal to the observed frequencies (Tabachnick \& Fidell, 2013). CFA is used to check Composite Reliability (CR) and AVE (Average Variance Extracted) values, as shown in Table 3. 
Table 3: Validity and reliability values

\begin{tabular}{c|cccccccccc}
\hline \multicolumn{2}{c}{ Factors } & AVE & CR & Cha & Con & Cust & Int & SP & OPI & eWOMM \\
\hline \multirow{4}{*}{ CIF } & Cha & 0.509 & 0.789 & $\mathbf{0 . 7 1 3}$ & 0.036 & 0.017 & 0.036 & 0.161 & 0.041 & 0.184 \\
& Con & 0.513 & 0.831 & 0.358 & $\mathbf{0 . 7 1 6}$ & -0.024 & 0.020 & 0.195 & -0.067 & 0.115 \\
& Cust & 0.608 & 0.857 & -0.110 & -0.040 & $\mathbf{0 . 7 8 0}$ & -0.021 & 0.078 & 0.115 & 0.132 \\
& \multirow{2}{*}{ Int } & $0.494^{*}$ & 0.785 & 0.158 & 0.274 & -0.039 & $\mathbf{0 . 7 0 3}$ & 0.022 & -0.068 & 0.218 \\
\multicolumn{2}{c}{ SP } & 0.717 & 0.952 & 0.208 & 0.217 & 0.084 & 0.069 & $\mathbf{0 . 8 4 7}$ & 0.029 & 0.271 \\
\multicolumn{2}{c}{ OPI } & 0.721 & 0.882 & 0.150 & 0.157 & 0.048 & 0.094 & 0.596 & $\mathbf{0 . 8 4 9}$ & -0.055 \\
\hline \multirow{2}{*}{ eWOMM } & 0.684 & 0.915 & 0.239 & 0.165 & 0.119 & 0.285 & 0.228 & 0.241 & $\mathbf{0 . 8 2 7}$ \\
\hline
\end{tabular}

Table 3 demonstrates that the $\mathrm{CR}$ values for all factors are within the desired confidence limits (greater than 0.70) and are highly reliable. According to Hair, Sarstedt, Hopkins \& Kuppelwieser (2014), CR values should be 0.60 or above. As shown in Table 3, all factors, except for the AVE value of the interaction factor, are above 0.50 (Cronbach, 1951; Perreault \& Russ, 1976; Peter, 1981; Peterson, 1994). If one of the AVE values is less than 0.50, then CR should be greater than 0.60 to ensure convergent validity (Fornell \& Larcker, 1981; Huang, Wang, Wu \& Wang, 2013). The square root of AVE values assesses discriminant validity. The diagonal values in Table 3 are obtained from the square root of AVE values. In addition, the values in the upper part of the diagonal in Table 3 give the Spearman correlation coefficients and the values in the lower part of the diagonal show the values of the latent variables. In Table 3, square roots of AVEs for the character, convenience, customization, contact interactivity, security and privacy, online purchasing intention, eWOMM were $0.713,0.716,0.780,0.703,0.847,0.849$ and 0.827 , respectively, and the square roots of AVEs were more significant than the correlations between constructs indicating the discriminant validity of each construct.

After EFA and CFA, SEM examines the relationships between the factors and verifies the research model. In this study, SEM and goodness-of-fit indices are made in two stages, which are Model 1 and Model 2. The goodness-of-fit indices for Model 1 are as follows: $\chi 2$ is 1221.923, $\chi 2$ / df is 2.504, RMSEA is $0.059, \mathrm{CFI}$ is 0.932 , NFI is $0.892, \mathrm{NNFI}$ is 0.922 , GFI is 0.898 , AGFI is 0.840 , RMR is 0.060 and SRMR is 0.055 . Based on the values in the literature, the values for Model 1 are generally at acceptable levels. For Model 2, the goodness of fit indices are as follows: $\chi 2$ is 1215.453, $\chi 2$ / df is 2.506, RMSEA is 0.059, CFI is 0.932 , NFI is 0.893 , NNFI is 0.922 , GFI is 0.869 , AGFI is 0.839 , RMR is 0.055 and SRMR is 0.050 . The values for Model 2 are generally at poor and acceptable levels. Therefore, the fit index values and comparison indices (AIC, CAIC and ECVI values) show a better fit in Model 2. In addition, Model 2 have the lowest value compared to Model 1 indices, and therefore Model 2 has a better fit than Model 1 .

Standardized coefficients, standard error, $t$ and $p$ values, upper, lower values and $p$ values of Bootstrap for the structural model are given in Table 4. The bootstrap method developed by Efron is the selection of sub-samples from the sample extracted from the population (Efron, 1979; Altaş \& Çinko, 2003). The bootstrap confidence interval is $95 \%$, and the resampling number is 5000 . Whether the hypotheses are supported is checked with the $\mathrm{p}$ values of the structural model. In addition, $\mathrm{p}$ values of Bootstrap are tested whether Bootstrap upper and lower values do not contain 0 (zero) to accept or reject the hypotheses (Bryne, 2010; Hayes, Preacher, \& Myers, 2011; Ulker-Demirel, Yuruk-Kayapinar \& Kayapinar, 2020). 
Table 4: Direct and indirect effects of the structural model and Bootstrap confidence interval values

\begin{tabular}{|c|c|c|c|c|c|c|c|c|c|}
\hline \multirow{2}{*}{\multicolumn{2}{|c|}{ Hyp. }} & \multirow{2}{*}{$\begin{array}{l}\text { Direct and Indirect } \\
\text { Effects }\end{array}$} & \multirow[b]{2}{*}{$\begin{array}{l}\text { Std. } \\
\text { Coef. }\end{array}$} & \multicolumn{2}{|c|}{ Path Coefficients } & \multirow[b]{2}{*}{$\begin{array}{c}\mathbf{p} \\
\text { Value}^{*}\end{array}$} & \multicolumn{3}{|c|}{$\begin{array}{l}\text { Bootstrap Confidence Interval } \\
(95 \%)^{* * *}\end{array}$} \\
\hline & & & & $\begin{array}{l}\text { Std. } \\
\text { Error }\end{array}$ & $\begin{array}{c}\mathrm{t} \\
\text { Value }\end{array}$ & & Lower & Upper & p-Value ${ }^{* *}$ \\
\hline \multirow{4}{*}{$\mathbf{H}_{1}$} & $\mathrm{H}_{1 \mathrm{a}}$ & Int $\rightarrow$ SP & 0.031 & 0.053 & 0.582 & 0.56 & -0.081 & 0.147 & 0.57 \\
\hline & $\mathrm{H}_{1 \mathrm{~b}}$ & Cust $\rightarrow$ SP & 0.103 & 0.047 & 2.173 & $0.03^{* *}$ & 0.007 & 0.208 & 0.04 \\
\hline & $\mathrm{H}_{1 \mathrm{c}}$ & Con $\rightarrow$ SP & 0.069 & 0.038 & 1.806 & 0.07 & -0.007 & 0.146 & 0.07 \\
\hline & $\mathrm{H}_{1 \mathrm{~d}}$ & Cha $\rightarrow$ SP & 0.100 & 0.044 & 2.283 & $0.02^{* *}$ & 0.009 & 0.199 & 0.03 \\
\hline \multirow{4}{*}{$\mathrm{H}_{2}$} & $\mathrm{H}_{2 \mathrm{a}}$ & Int $\rightarrow$ eWOMM & 0.260 & 0.065 & 3.969 & $0.00^{*}$ & 0.109 & 0.464 & 0.00 \\
\hline & $\mathbf{H}_{2 b}$ & Cust $\rightarrow$ eWOMM & 0.163 & 0.056 & 2.913 & $0.00^{*}$ & 0.053 & 0.286 & 0.01 \\
\hline & $\mathbf{H}_{2 c}$ & Con $\rightarrow \mathrm{eWOMM}$ & -0.007 & 0.044 & -0.152 & 0.88 & -0.097 & 0.084 & 0.89 \\
\hline & $\mathbf{H}_{2 \mathrm{~d}}$ & Cha $\rightarrow$ eWOMM & 0.169 & 0.052 & 3.236 & $0.00^{*}$ & 0.061 & 0.283 & 0.00 \\
\hline $\mathrm{H}_{3}$ & $\mathrm{H}_{3}$ & $\mathrm{SP} \rightarrow \mathrm{eWOMM}$ & 0.140 & 0.052 & 2.445 & $0.01^{*}$ & 0.004 & 0.274 & 0.04 \\
\hline \multirow{4}{*}{$\mathbf{H}_{4}$} & $\overline{\mathrm{H}_{4 a}}$ & Int $\rightarrow$ OPI & -0.062 & 0.033 & -1.861 & 0.06 & -0.124 & -0.003 & 0.04 \\
\hline & $\mathbf{H}_{4 \mathrm{~b}}$ & Cust $\rightarrow$ OPI & 0.057 & 0.029 & 1.964 & $0.05^{* *}$ & 0.003 & 0.115 & 0.05 \\
\hline & $\mathbf{H}_{4 \mathrm{c}}$ & Cha $\rightarrow$ OPI & 0.018 & 0.027 & 0.673 & 0.54 & -0.041 & 0.067 & 0.55 \\
\hline & $\mathrm{H}_{4 \mathrm{~d}}$ & Con $\rightarrow$ OPI & -0.002 & 0.023 & -0.086 & 0.93 & -0.050 & 0.060 & 0.95 \\
\hline $\mathrm{H}_{5}$ & $\mathrm{H}_{5}$ & eWOMM $\rightarrow$ OPI & 0.003 & 0.027 & 0.107 & 0.92 & -0.053 & 0.067 & 0.96 \\
\hline \multirow{4}{*}{$\mathrm{H}_{6}$} & $\mathrm{H}_{6 a}$ & Int $\rightarrow \mathrm{SP} \rightarrow \mathrm{eWOMM}$ & 0.04 & & & & -0.010 & 0.031 & 0.42 \\
\hline & $\mathrm{H}_{6 \mathrm{~b}}$ & Cust $\rightarrow \mathrm{SP} \rightarrow \mathrm{eWOMM}$ & 0.014 & & & & 0.000 & 0.045 & 0.05 \\
\hline & $\mathrm{H}_{6 \mathrm{c}}$ & Con $\rightarrow \mathrm{SP} \rightarrow \mathrm{eWOMM}$ & 0.010 & & & & 0.000 & 0.030 & 0.05 \\
\hline & $\mathrm{H}_{6 \mathrm{~d}}$ & $\mathrm{Cha} \rightarrow \mathrm{SP} \rightarrow \mathrm{eWOMM}$ & 0.014 & & & & 0.000 & 0.045 & 0.04 \\
\hline
\end{tabular}

${ }^{*} \mathrm{p}<0.01 .{ }^{* *} \mathrm{p}<0.05$. ${ }^{* * *}$ Bootstrap based on 5000 samples.

The results in Table 4 show that customization and character directly affect security and privacy. Moreover, at the 0.05 significance level, $\mathrm{p}$ values are 0.03 and 0.02 , respectively; therefore, hypotheses $\mathrm{H} 1 \mathrm{~b}$ and $\mathrm{H} 1 \mathrm{~d}$ are supported because the upper and lower values of Bootstrap analysis in Table 4 do not contain zero, and the p-value is 0.04 and 0.03 . On the other hand, H1a and H1c hypotheses are rejected because $p$ values are insignificant at 0.05 significance level and more excellent than 0.05 .

Contact interactivity, customization, and character of CIF factors directly affect eWOMM, and p values are 0.00 at a significance level of 0.05 ; therefore, $\mathrm{H} 2 \mathrm{a}, \mathrm{H} 2 \mathrm{~b}$ and $\mathrm{H} 2 \mathrm{~d}$ hypotheses are accepted. Bootstrap values show that the upper and lower values do not contain zero and are supported because $\mathrm{p}$ values are $0.00,0.01$ and 0.00 . Security and privacy directly affect eWOMM. The p-value is $0.01, \mathrm{H} 3$ is supported, lower and upper values do not include zero, and the p-value is 0.05 . Therefore, there is a significant effect of security and privacy on eWOMM at a 0.05 significance level.

For the sub-hypotheses under the H4, the only customization directly affects online purchasing intention, and $\mathrm{p}$ values are significant at a 0.05 significance level. Therefore, H4b is accepted while H4a, $\mathrm{H} 4 \mathrm{c}$ and $\mathrm{H} 4 \mathrm{~d}$ are rejected at a 0.05 significance level.

eWOMM has no effect at 0.05 significance level on online purchasing intention, supported by Bootstrap analysis results. It contains zero between upper and lower values, and the p-value supports this. Therefore, $\mathrm{H} 5$ is rejected at a significance level of 0.05 .

Finally, customization and character are significant at a 0.05 significance level for the mediation effect of security and privacy in the relationship between customer interface features and online purchasing intention (H6). As shown in Table 5, customization and character are directly and significantly related to eWOMM. Besides, there is a significant relationship between customization and character and eWOMM with a partial mediating effect of security and privacy. Model 2, including the direct effects, is tested to test the mediation effect, and there is no mediation effect of security and privacy. The results for the direct effects of customization and character on eWOMM are $\beta$ cust-eWOMM $=0.163 ; \mathrm{p}<0.05$ and $\beta$ cha-eWOMM $=0.169 ; \mathrm{p}<0.05$ at 0.05 significance level, respectively. When the mediating effect of security and privacy is added to the model, the result is $\beta$ cust-SP-eWOMM $=0.014 ; \mathrm{p}<0.05$ and $\beta$ cha-SPeWOMM $=0.014 ; \mathrm{p}<0.05$ at 0.05 significance level. Bootstrap values show that both variables indirectly affect eWOMM via security and privacy at a 0.05 significance level. While the value of customization's direct effect on eWOMM is $\beta$ cust-eWOMM $=0.163$, it changes to $\beta$ cust-SP-eWOMM $=0.014$ with the mediation effect of security and privacy. Similarly, while the value of a character's direct effect on $\mathrm{eWOMM}$ is $\beta$ cha-eWOMM $=0.169$, it changes to $\beta$ cha-SP-eWOMM $=0.014$ with security and privacy 
mediation effect. Therefore, customization and character variables seem to have a significant, partial and reducing mediating effect at the level of 0.05 . In order to test the significance of this decrease as a result of the mediation (Sobel, 1982), the SOBEL test is applied to the variables. SOBEL test results show that the decrease is significant (Zcust $=1.976 ; p=0.05$ ). The significance of the decrease resulting from mediation for the character is $Z \mathrm{cha}=2.073 ; \mathrm{p}=0.04$. Therefore, the decreases in both variables are significant at a 0.05 significance level.

Table 5: Standardized coefficients for direct, indirect and total effects of the structural model

\begin{tabular}{|c|c|c|c|c|c|c|c|}
\hline \multicolumn{8}{|c|}{ Std. Total Effect } \\
\hline & Cha & Con & Cust & Int & SP & eWOMM & OPI \\
\hline $\mathrm{SP}$ & $0.100^{* *}$ & 0.069 & $0.102^{* *}$ & 0.032 & - & - & - \\
\hline eWOMM & $0.183^{*}$ & 0.003 & $0.177^{*}$ & $0.264^{*}$ & $0.140^{*}$ & - & - \\
\hline OPI & 0.016 & -0.003 & $0.055^{* *}$ & -0.062 & - & 0.001 & - \\
\hline \multicolumn{8}{|c|}{ Std. Direct Effect } \\
\hline & Cha & Con & Cust & Int & SP & eWOMM & OPI \\
\hline SP & $0.100^{* *}$ & 0.069 & $0.102^{* *}$ & 0.032 & - & - & - \\
\hline eWOMM & $0.169^{*}$ & -0.007 & $0.163^{*}$ & $0.260^{*}$ & $0.140^{*}$ & - & - \\
\hline OPI & 0.016 & -0.003 & $0.055^{* *}$ & -0.062 & - & 0.001 & - \\
\hline \multicolumn{8}{|c|}{ Std. Indirect Effect } \\
\hline & Cha & Con & Cust & Int & SP & eWOMM & OPI \\
\hline SP & - & - & - & - & - & - & - \\
\hline eWOMM & $0.014^{* *}$ & 0.010 & $0.014^{* *}$ & 0.004 & - & - & - \\
\hline OPI & - & - & - & - & - & - & - \\
\hline
\end{tabular}

Table 5 shows the standardized coefficients needed to formulate the direct, indirect and total effects obtained from the hypothesis test results in Table 4 . Next, structural equation formulas are formed based on the results shown in Table 5. Finally, R2 values of the structural equations are shown in Table 6.

Table 6: $\mathrm{R}^{2}$ values of direct and indirect structural equations

\begin{tabular}{|c|c|c|}
\hline & $\begin{array}{l}\text { Structural Equation } \\
\text { (Direct Effects) }\end{array}$ & $\mathbf{R}^{2}$ \\
\hline 1 & $\mathrm{SP}=0.100 \mathrm{Cha}+0.102$ Cust & 0.047 \\
\hline 2 & $\mathrm{eWOM} \mathrm{M}=0.183 \mathrm{Cha}+0.177 \mathrm{Cust}+0.264 \mathrm{Int}+0.140 \mathrm{SP}$ & 0.133 \\
\hline \multirow[t]{2}{*}{3} & $\mathrm{OPI}=0.105$ Cust & 0.024 \\
\hline & $\begin{array}{l}\text { Structural Equation } \\
\text { (Indirect Effects) }\end{array}$ & \\
\hline 4 & $\mathrm{eWOMM}=0.014$ Cha +0.014 Cust & 0.113 \\
\hline
\end{tabular}

Table 6 shows how much of the direct and indirect relationships between variables can be explained by R2 values. Results show that $4.7 \%$ of security and privacy is explained by character and customization at a 0.05 significance level. A one-unit increase in character and customization will cause an increase of 0.202 units in security and privacy. Therefore, character and customization seem to affect security and privacy. According to Formula 2, 13.3\% of the eWOMM is explained by 0.05 significance level by character, convenience and customization and security and privacy. In this effect, eWOMM is explained by an interaction variable with a maximum coefficient of 0.264 and a minimum coefficient of 0.140 by security and privacy. According to Formula 3, the only customization directly affects and explains $2.4 \%$ of online purchasing intention. Finally, Formula 4 shows that $13.3 \%$ of eWOMM is explained by customization and character through security and privacy at a 0.05 significance level.

\section{Conclusion}

With globalization and changes in technology, the activities of businesses and consumers over the Internet have significantly diversified, which has changed their preferences and behaviours as well. While businesses carry out their transactions related to their goods and services over the Internet, 
consumers have started to make their purchases using the Internet. Consumers search for a product, make their purchases and share their experiences on the Internet. Therefore, customer interface features of an e-commerce website gain utmost importance as they have a significant effect on consumer behaviour e-commerce website. If customers like the customer interface features of an e-commerce website, they are more likely to perceive both the website and their purchase experiences as of high quality. If consumers are satisfied with the customer interface features, they will likely have a seamless purchase experience. However, good customer interface features alone are not enough for consumers in some cases because most consumers shopping from an e-commerce site want their personal information to be kept secret and secure and not to be shared with others. Therefore, the security and privacy offered by an e-commerce site become one of the essential elements for consumers. The present study examines customer interface features, security and privacy, electronic word of mouth marketing, and online purchasing intention. The results revealed that customization and character seemed to directly affect security and privacy, which is in line with the findings of Kim, Ferrin \& Rao (2008) and Belanger et al. (2002), who suggested that the quality of a website will generate greater trust in consumers. All these results point out that security and privacy are determining and essential factors in website quality in line with the studies of Ackerman. et al. (1999), Anton et al., (2002) and Li (2014). The variables of contact interactivity, character, and customization directly affect eWOMM, whereas the only customization seems to affect online purchasing intention directly. The results support the findings of Scholosser et al. (2006), Constantinides (2004) and Sam et al. (2009). Security and privacy have a direct effect on eWOMM, which is in line with the findings of Kim \& Kim (2004), Kim et al. (2009), Miyazaki \& Fernandez (2001) and Chung \& Shin (2010). Therefore, as suggested by Wolfinbarger \& Gilly (2003) and Szymanski \& Hise (2000), the security of a website and the privacy of customers' personal information make online shopping experiences meaningful.

The studies of Bickart \& Schindler (2001), Chevalier \& Mayzlin (2006), See-To \& Ho (2014), Erkan \& Evans (2016), Martinez-Navarro \& Bigne (2017) have demonstrated that eWOMM is an essential factor affecting consumers' purchasing intentions. However, the results of this study reveal that eWOMM does not directly affect consumers' purchasing intentions and therefore does not comply with the findings of the studies above. Replicating these studies with consumers from different backgrounds may reveal different results. In addition, there is an indirect relationship between customization and character and eWOMM via security and privacy.

The structural equations show that $4.7 \%$ of security and privacy are explained by character and customization at 0.05 significance level, and one unit increase in these variables causes an increase of 0.202 units on security and privacy. Therefore, a change in character and customization also leads to a change in security and privacy. In another structural equation, $13.3 \%$ of eWOMM are explained by character, convenience and customization and security and privacy at 0.05 significance level, where contact interactivity has a maximum coefficient of 0.264 , and security and privacy have a minimum coefficient 0.140 . In another structural equation, customisation directly affects only online purchasing intention, which explains $2.4 \%$ of the online purchasing intention. Finally, customization and character explain $13.3 \%$ of eWOMM via security and privacy at a 0.05 significance level in the structural equation for the mediation effect.

All these results point out that customer interface features, security and privacy are of utmost importance for consumers' electronic word of mouth marketing behaviours and online purchasing intention. Therefore, the present study may guide businesses and future studies in the field. However, future studies employing different variables and sample sizes and recruiting consumers from different backgrounds might yield different results. Since the study has material and time constraints, working with larger samples and longer durations may provide more accurate results. Furthermore, the results that contact interactivity and convenience have not a direct effect on security/privacy, and intention to purchase online and the lack of indirect effects of contact interactivity and convenience on electronic word of mouth marketing through security and privacy suggest that these variables are not fully understood by consumers or are not that important to them. When the generally rejected hypotheses are examined, it is seen that the study sample does not attach much importance to the convenience and contact interactivity of the website. Instead, consumers want to spend more time on a website that makes them feel special, fully responsive to their wishes and needs, and whose design they like. Therefore, in this study, the personalization variable becomes especially important for them. The study 
mainly consisted of young participants between the ages of 28-36 who may support this situation. Because other participants may be more attentive and cautious, especially in their purchasing behaviours due to their age, for this reason, they gave importance to the different features of a website.

Therefore, future studies may use different scales where these variables are emphasized. The results also show that security and privacy are fundamental to customers shopping from an e-commerce site. Therefore, paying particular attention to this variable in practical life will make customers feel more comfortable to shop from an e-commerce site and encourage them to share their positive experiences with others. Lastly, these findings may guide businesspeople in deciding the customer profiles chosen as the current study sample.

\section{Limitation and future research}

The limitations of this study offer opportunities for use in future research. The data were collected in a certain period. The research can be expanded by collecting more data at a different time, in a more prominent place, and over a more extended period to increase the generalizability of the results. In addition, the sample of this study was collected in only three cities in the Thrace region. Research collected with a more dispersed sample will also increase the generalizability of the subject.

Srinivasan et al. (2002) 's study has been used to examine customer interface features in the current study. However, customer interface features have been handled and collected by different authors using different variables. Therefore, in another study, customer interface features taken from different authors will provide different results.

Although the participants in this study are real internet users, they do not represent all consumers. For example, a relationship was not established in this study according to the demographic characteristics of the participants. Nevertheless, the results for younger consumers and older consumers are likely to be different. This situation can be examined in future studies. In the study, consumers who buy through an e-commerce site have been studied, and the features of the e-commerce site, such as which sector it is in, which products are purchased, have been ignored. In future, research can be done by considering different sectors or different products.

In addition to all these, the results of this study provide actual data for e-commerce site designers. One of the most important results obtained in this research is related to the security and privacy factors of the e-commerce site. Especially businesses should pay attention to this factor and avoid any activity that would endanger customers' information because customers want businesses to offer them a safe environment in every shopping. Also, E-commerce site designers should design a website that will make customers spend minimal effort. It is essential that the website is easy to use and the increased quality graphics and multimedia options. They should make their websites compatible with mobile devices and expand their mobile interface options so that the customers enjoy their shopping, get excited, develop a sense of satisfaction and not go to their competitors. Using too many pages on the ecommerce site will increase the number and time of clicks and page scrolls. For this reason, customers will be bored, bored, and their perception rate in an e-commerce site will decrease. Businesses should pay attention to all this.

\section{Peer-review:}

Externally peer-reviewed

\section{Conflict of interests:}

The author(s) has (have) no conflict of interest to declare.

\section{Grant Support:}

The authors declared that this study has received no financial support 


\section{References}

Ackerman, M. S., Cranor, L. F. \& Reagle, J. (1999). Privacy in e-commerce: examining user scenarios and privacy preferences. Paper Presented at the 1st ACM conference on Electronic commerce (1-8). ACM.

Aladwani, A. M. \& Palvia, P. C. (2002). Developing and Validating an Instrument for Measuring UserPerceived Web Quality. Information \& Management, 39, 467-476.

Alpar, R. (2013). Uygulamalı Çok Değişkenli Istatistiksel Yö̈temler. Ankara: Detay Yayıncılık.

Altaş, D. \& Çinko, M. (2003). Bootstrap yönteminin Ridge Regresyonda uygulanması. Uludă̆g Üniversitesi İktisadi ve İdari Bilimler Fakültesi Dergisi, 22(1), 281-292.

Antón, A. I., Earp, J. B. \& Reese, A. (2002). Analyzing website privacy requirements using a privacy goal taxonomy. In Proceedings IEEE Joint International Conference on Requirements Engineering (23-31). IEEE.

Ardiansah, M., Chariri, A., Rahardja, S., \& Udin, U. (2020). The effect of electronic payments security on e-commerce consumer perception: An extended model of technology acceptance. Management Science Letters, 10(7), 1473-1480.

Belanger, F., Hiller, J. S. \& Smith, W. J. (2002). Trustworthiness in electronic commerce: the role of privacy, security, and site attributes. The Journal of Strategic Information Systems, 11(3-4), 245-270.

Bickart, B. \& Schindler, R. B. (2001). Internet forums as influential sources of consumer information. Journal of Interactive Marketing, 15(3), 31-40.

Bridges E. \& Florsheim, R. (2008). Hedonic and utilitarian shopping goals: the online experience. Journal of Business Research, 61(4), 309-314.

Brown, J., Broderick, A. J. \& Lee, N. (2007). Word of mouth communication within online communities: conceptualizing the online social network. Journal of Interactive Marketing, 21(3), 2-20.

Byrne, B. M. (2010). Structural Equation Modelling with Amos, Basic Consepts, Applications, and Programing. New York: Routledge Taylor and Francis Group.

Cengiz, E. \& Şekerkaya, A. (2010). İnternet kullanıcılarının Internetten alışverişe yönelik satın alma karar süreçlerinin incelenmesi ve kullanım yoğunlukları açısından sınıflandırılması üzerine bir araştırma. Öneri Dergisi, 9(33), 33-49.

Chang, H. H. \& Chen, S.W. (2008a). The impact of customer interface quality, satisfaction and switching costs on e-loyalty: Internet experience as a moderator. Computers in Human Behavior, 24(6), 2927-2944.

Chang, H. H. \& Chen, S. W. (2008b). The impact of online store environment cues on purchase intention: trust and perceived risk as a mediator. Online Information Review, 32(6), 818-841.

Chevalier, J. A. \& Mayzlin, D. (2006). The effect of word of mouth on sales: online book reviews', Journal of Marketing Research, 43(3), 345-354.

Chung, K. H. \& Shin, J. I. (2010). The antecedents and consequents of relationship quality in Internet shopping. Asia Pacific Journal of Marketing and Logistics, 22(4), 473-491.

Constantinides, E. (2004). Influencing the online consumer's behavior: The Web experience. Internet research, 14(2), 111-126.

Corbitt, B. J., Thanasankit, T. \& Yi, H. (2003). trust and e-commerce: a study of consumer perceptions. Electronic commerce research and applications, 2(3), 203-215.

Cronbach, L. J. (1951). Coefficient alpha and the internal structure of tests. Psychometrika, 16(3), .297-334. 
Efron, B. (1979). Bootstrap methods: another look at the jackknife. The Annals of Statistics, 7(1), 1-26.

Erkan, I. \& Evans, C. (2016). Social media or shopping websites? the influence of ewom on consumers' online purchase intentions. Journal of Marketing Communications, 24(6), 617-632.

Fabrigar, L. R., Maccallum, R. C., Wegener, D. T. \& Strahan, E. J. (1999). Evaluating the use of exploratory factor analysis in psychological research. Psychological Method, 4(3), 277-299.

Forgas-Coll, S., Palau-Saumell, R., Sanchez-Garcia, J. \& Fandos-Roig, J. C. (2013). Airline website loyalty formation and the moderating effects of gender and education. Service Business, 7, 255-274.

Fornell, C. \& Larcker, D. F., (1981). Evaluating structural equation models with unobservable variables and measurement error. Journal of Marketing Research, 18(1), 39-50.

Gefen, D. (2000). E-commerce: the role of familiarity and trust. Omega, 28(6), 725-737.

Gegez, A. E. (2010). Pazarlama Araştırmaları. İstanbul: Beta Yayıncılık, 3. Baskı.

Girsang, M. J., Hendayani, R., \& Ganesan, Y. (2020). Can Information Security, Privacy and Satisfaction Influence The E-Commerce Consumer Trust?. In 2020 8th International Conference on Information and Communication Technology (ICoICT) (pp. 1-7). IEEE.

Ha, Y. \& Im, H. (2012). Role of web site design quality in satisfaction and word of mouth generation. Journal of Service Management, 23(1), 79-96.

Hair, J. F., Black, W. C., Babin, B. J. \& Anderson, R. E. (2009). Multivariate data analysis: a global perspective. ABD: Pearson, 7. Baskı.

Hair, J. F., Black, W. C., \& Babin, B. J. (2010). Multivariate Data Analysis: A Global Perspective. Pearson Education.

Hair, J. J. F., Sarstedt, M., Hopkins, L., \& G. Kuppelwieser, V. (2014). Partial least squares structural equation modeling (PLS-SEM) an emerging tool in business research. European Business Review, 26(2), 106-121.

Hayes, A. F., Preacher, K. J., \& Myers, T. A. (2011). Mediation and the estimation of indirect effects in political communication research. In P. Bucy, \& R. L. Holbert (Eds.), The sourcebook for political communication Research: Methods, measures, and analytical techniques (pp. 434e465). New York: Routledge.

Hayes, A. F. (2013). Introduction to Mediation, Moderation, and Conditional Process Analysis: A RegressionBased Approach. New York: Guilford Press.

Heijden, H. V. D., Verhagen, T. \& Creemers, M. (2003). Understanding online purchase intentions: contributions from technology and trust perspectives. European Journal of Information Systems, 12, 4148.

Ho C. \& Lee, Y. L. (2007). The development of an e-travel service quality scale. Tourism Management, 28(6), 1434-1449.

Hooper, D., Coughlan, J. \& Mullen, M., (2008). Structural equation modelling: Guidelines for determining model fit. Electronic Journal of Business Research Methods, 6(1), 53-60.

Huang, C.-C., Wang, Y.-M., Wu, T.-W. \& Wang, P.-A. (2013). An empirical analysis of the antecedents and performance consequences of using the moodle platform. International Journal of Informationa nd Education Technology, 3(2), 217-221.

Hui, K-L., Teo, H. H. \& Lee, S-Y.T. (2007). The value of privacy assurance: an exploratory field experiment. MIS Quarterly, 31(1), 19-33. 
Hu, L. \& Bentler, P. M. (1999). Cutoff criteria for fit indexes in covariance structure analysis: Conventional criteria versus new alternatives. Structural Equation Modeling: A Multidisciplinary Journal, 6(1), 1-55.

Islam, H., Jebarajakirthy, C., \& Shankar, A. (2021). An experimental based investigation into the effects of website interactivity on customer behavior in online purchase context. Journal of Strategic Marketing, 29(2), 117-140.

Kaiser, H. F. \& Rice, J. (1974). Little Jiffy Mark IV. Educational and Psychological Measurement, 34, 111-117.

Kayapınar, Ö. (2018). Pazarlama araştırmalarında güncel gelişmeler. Altuğ, N. \& Özhan, Ş. (Ed.). Pazarlamada Güncel Gelişmeler. (ss.571-603). Ankara: Nobel Akademik Yayıncılık.

Kazmi, S. H. A., Hai, L. C. \& Abid M. M. (2016). Online purchase intentions in e-commerce. 8. International Conference on Intelligent Human-Machine Systems and Cybernetics.

Kim, E Y. \& Kim, Y. K. (2004). Predicting online purchase intentions for clothing products. European Journal of Marketing, 38(7), 883-897.

Kim, D. J., Ferrin, D. L. \& Rao, H. R. (2008). A trust-based consumer decision-making model in electronic commerce: the role of trust, perceived risk, and their antecedents. Decision Support Systems, 44, 544564.

Kim, J., Jin, B. \& Swinney, J. L. (2009). The role of etail quality, e-satisfaction and e-trust in online loyalty development process. Journal of Retailing and Consumer Services, 16, 239-247.

Kline, R. B. (2005). Principles and Practice of Structural Equation Modeling. New York: The Guilford Press.

Kline, R. B. (2011). Principles and Practice of Structural Equation Modelling. New York: The Guilford Press.

Jalilvand, M. R. \& Samiei, N. (2012). The effect of electronic word of mouth on brand image and purchase intention: an empirical study in the automobile industry in Iran. Marketing Intelligence $\mathcal{E}$ Planning, 30(4), 460-476.

Lee, Y. E. \& Benbasat, I. (2004). A framework for the study of customer interface design for mobile commerce. International Journal of Electronic Commerce, 8(3), 79-102.

Li, Y. (2014). The impact of disposition to privacy, website reputation and website familiarity on information privacy concerns. Decision support systems, 57, 343-354.

Lim, Y. J., Osman, A., Salahuddin, S. N., Romle, A. R. \& Abdullah, S. (2016). Factors influencing online shopping behaviour: the mediating role of purchase intention. Procedia Economics and Finance, 35, 401-410.

López, M. \& Sicilia, M. (2014). Determinants of E-WOM influence: the role of consumers' Internet experience. Journal of Theoretical and Applied Electronic Commerce Research, 9(1), 28-43.

Martínez-Navarro, J. \& Bigné, E. (2017). The value of marketer-generated content on social network sites: media antecedents and behavioral responses. Journal of Electronic Commerce Research, 18(1), 5272.

McCole, P., Ramsey, E. \& Williams, J. (2010). Trust considerations on attitudes towards online purchasing: The moderating effect of privacy and security concerns. Journal of Business Research, 63, (9-10), 1018-1024.

McDowell, W. C., Wilson, R. C. \& Kile, C. O. (2016). An examination of retail website design and conversion rate. Journal of Business Research, 69, 4837-4842. 
Mirabi, V., Akbariyeh, H. \& Tahmasebifard, H. (2015). A study of factors affecting on customers purchase intention, case study: the agencies of bono brand tile in Tehran. Journal of Multidiciplinary Engineering Science and Technology, 2(1), 267-273.

Miyazaki, A. D. \& Fernandez, A. (2001). Consumer perceptions of privacy and security risks for online shopping. The Journal of Consumer Affairs, 35(1), 27-44.

Ngarmwongnoi, C., Oliveira, J. S., AbedRabbo, M., \& Mousavi, S. (2020). The implications of eWOM adoption on the customer journey. Journal of Consumer Marketing, 37(7), 749-759.

Perreault, W. D. \& Russ, F. A., (1976). Physical distribution service in industrial purchase decisions. Journal of Marketing, 40(2), 3-10.

Perreault, W. D. Jr, \& Leigh, L. E. (1989). Reliability of nominal data based on qualitative judgments. Journal of Marketing Research, 26(2), 135-148.

Peter, J. P. (1981). Construct validity: A review of basic issues and marketing practices. Journal of Marketing Research, 18(2), 133-145.

Peterson, R. A. (1994). A meta-analysis of Cronbach's coefficient alpha. Journal of Consumer Research, 21(2),.381-391.

Rosario, A. B., de Valck, K., \& Sotgiu, F. (2020). Conceptualizing the electronic word-of-mouth process: What we know and need to know about eWOM creation, exposure, and evaluation. Journal of the Academy of Marketing Science, 48(3), 422-448.

Sam, M., Fazli, M. \& Tahir, M. N. H. (2009). Website quality and consumer online purchase intention of air ticket. International Journal of Basic \& Applied Sciences, 9(10), 20-25.

Schermelleh-Engel, K., Moosbrugger, H. \& Müller, H., (2003). Evaluating the fit of structural equation models: Tests of significance and descriptive goodness-of-fit measures. Methods of Psychological Research Online, 8(2), 23-74.

Schaffer, E. (2000). A better way for web design. Information Week, 784, 194-195.

Schlosser, A. E., White, T. B. \& Lloyd, S. M. (2006). Converting web site visitors into buyers: how web site investment increases consumer trusting beliefs and online purchase intentions. Journal of Marketing, 70(2), 133-148.

See-To, E. W. K. \& Ho, K. K. W. (2014). Value co-creation and purchase intention in social network sites: the role of electronic word-of-mouth and trust - a theoretical analysis. Computers in Human Behavior, 31, 182-189.

Serra-Cantallops, A., Cardona, J. R., \& Salvi, F. (2020). Antecedents of positive eWOM in hotels. Exploring the relative role of satisfaction, quality and positive emotional experiences. International Journal of Contemporary Hospitality Management, 32(11), 3457-3477.

Siahaya, J. C., Amelia, \& Suryaputra, R. (2021). Analysis of the effect of application design, customer service, security and privacy, and fulfilment dimensions to customer satisfaction and repurchase intention of Blibli.com customers in Surabaya. International Journal of Research Publications, 69(1), 367382.

Sin, L. \& Tse, A. (2002). Profiling Internet shoppers in Hong Kong: demographic, psychographic, attitudinal and experiential factors. Journal of Interactive Marketing, 15(1), 7-29.

Slyke, C. V. (2002). Gender differences in perceptions of web-based shopping. Communications of the ACM, 47(7), 82-86. 
Sobel, M. E. (1982). Asymptotic confidence intervals for indirect effects in structural equations models. Sociological methodology, 13, 290-312.

Srinivasan, S. S., Anderson, R. \& Ponnavolu, K. (2002). Customer loyaty in e-commerce: an exploration of its antecedents and consequences. Journal of Retailing, 78, 41-50.

Szymanski, D. M. \& Hise, R. T. (2000). E-satisfaction: an initial examination. Journal of Retailing, 76(3), 309-322.

Tabachnick, B. G. \& Fidell, L. S. (2013). Using Multivariate Statistics. New Jersey: Pearson.

Thamizhvanan, A. \& Xavier, M. J. (2013). Determinants of customers' online purchase intention: an empirical study in India. Journal of Indian Business Research, 5(1), 17-32.

Tran, G. A., Strutton, D. \& Taylor, D. G. (2012). Do microblog postings influence consumer perceptions of retailers' e-servicescapes?. Management Research Review, 35(9), 818-836.

Ulker-Demirel, E., Yuruk-Kayapinar, P., \& Kayapinar, O. (2020). The role of consumer ethnocentrism on boycott behaviour: What if a domestic business behaves egregiously? Canadian Journal of Administrative Sciences/Revue Canadienne des Sciences de l'Administration. Early view.

Verhagen, T. \& Dolen, W. V. (2009). Online purchase intentions: a multi-channel store image perspective. Information \& Management, 46, 77-82.

Vila, T. D., González, E. A., Vila, N. A., \& Brea, J. A. F. (2021). Indicators of Website Features in the User Experience of E-Tourism Search and Metasearch Engines. Journal of theoretical and applied electronic commerce research, 16(1), 18-36.

Wang, Y.D. \& Emurian, H.H. (2005). Trust in e-commerce: consideration of interface design factors. Journal of Electronic Commerce in Organizations, 3(4), 42-60.

Wolfinbarger, M. \& Gilly, M. C. (2003). eTailQ: dimensionalizing, measuring and predicting etail quality. Journal of Retailing, 79, 183-198.

Yoo, B. \& Donthu, N. (2001). Developing a scale to measure the perceived quality of an internet shopping site (SITEQUAL). Quarterly Journal of Electronic Commerce, 2(1), 31-47.

Yoo, C. W., Sanders, G. L. \& Moon, J. (2013). Exploring the effect of e-WOM participation on e-Loyalty in e-commerce. Decision Support Systems, 55(3), 669-678.

Yuruk-Kayapinar, P. (2020). Digital Consumer Behavior in an Omnichannel World. In Managing Customer Experiences in an Omnichannel World: Melody of Online and Offline Environments in the Customer Journey. Emerald Publishing Limited.

Zhang, Y., Fiore, A. M., Zhang, L., \& Liu, X. (2020). Impact of website design features on experiential value and patronage intention toward online mass customization sites. Journal of Fashion Marketing and Management: An International Journal, 25(2), 205-223. 